\title{
Analysis of technical disallowances in a surgical center of a private general hospital
}

\author{
Análise de glosas técnicas em centro cirúrgico de hospital geral privado
}

Raquel Silva Bicalho Zunta ${ }^{1}$, Antônio Fernandes Costa Lima²

Objective: to analyze technical disallowances in a surgical center of a private general hospital. Methods: retrospective documentary study with a sample of 383 medical records with disallowed hospital accounts in which the percentages of disallowances were evaluated through Generalized Estimating Equation models. Results: 1,373 items were disallowed, $82.1 \%$ corresponded to nursing professionals and $17.9 \%$ to anesthesiologist physicians. The "materials" and "medicines" accounting groups presented the greater number of items disallowed: $67.7 \%$ and $13.2 \%$, respectively. The highest amount of disallowed items was generated by nursing professionals, however the highest percentage corresponded to anesthetist physicians. Conclusion: the analysis of hospital accounts allowed the calculation of the number of technical disallowances, with a total of 1,373 items. Nursing professionals were responsible for most of the disallowed items, and the "materials" accounting group predominated, contributing to the search for alternatives that increase billing in the surgical center studied.

Descriptors: Surgicenters; Health Personnel; Documentation; Billing; Costs and Cost Analysis.

Objetivo: analisar glosas técnicas geradas em centro cirúrgico de hospital geral privado. Métodos: pesquisa documental retrospectiva, cuja amostra constituiu-se de 383 prontuários com contas hospitalares glosadas, nas quais foram avaliadas as porcentagens de glosa, por intermédio de modelos de Equações de Estimação Generalizadas. Resultados: foram glosados 1.373 itens, $82,1 \%$ correspondentes aos profissionais de enfermagem e 17,9\% aos médicos anestesistas. Os grupos contábeis "materiais" e "medicamentos" apresentaram os itens mais glosados, $67,7 \%$ e $13,2 \%$, respectivamente. A maior quantidade de itens glosados foi gerada por profissionais de enfermagem, contudo a porcentagem mais elevada correspondeu aos médicos anestesistas. Conclusão: a análise das contas hospitalares subsidiou o cálculo do número de glosas técnicas, com total de 1.373 itens, sendo os profissionais de enfermagem responsáveis pela maioria dos itens glosados e com predominância do grupo contábil "materiais", contribuindo para busca de alternativas que incrementem o faturamento no centro cirúrgico pesquisado.

Descritores: Centros Cirúrgicos; Pessoal de Saúde; Documentação; Faturamento; Custos e Análise de Custo.

\footnotetext{
${ }^{1}$ Centro Universitário Adventista de São Paulo. São Paulo, SP, Brazil.

${ }^{2}$ Universidade de São Paulo. São Paulo, SP, Brazil. 


\section{Introduction}

In hospital financial administration, records made in the patient's chart are often audited due to their importance to portray the provision of health services and the close relationship with the healthcare billing process ${ }^{(1)}$. In this process, financial losses can be caused by different reasons, such as non-collection of materials, medicines and diagnostic support services; failure to meet billing deadlines; and non-delivery of services rendered by tables of outdated procedures and disallowances.

Disallowances refer to the partial or total non-payment of a certain procedure or service. They are divided into administrative, resulting from operational failures (errors in hospital bill invoice), and technical, when the account presents nonconformities regarding the records made. Such failures in the records negatively affect the hospital institution in the technical aspect, for continuity of care, and in the financial aspect, regarding the eligibility of hospital charges related to the actual payment made by the provider. Thus, through auditing nurses, managers seek to reduce the accounting impact caused by disallowances on hospital bills ${ }^{(2)}$.

In hospital organizations, the Surgical Centers are considered critical units with respect to the occurrence of disallowances. In the Brazilian reality, the surgical team, composed of medical surgeons, anesthetist physicians, nurses, technicians and nursing assistants $^{(3)}$, is responsible for the documentation of information indispensable to the care process in a clear, readable, objective and comprehensive way (date, time, signature and professional registration number) ${ }^{(4-5)}$.

The trustworthy registry mirrors the efficiency and veracity of the care provided, constituting a legal guarantee for clients, health professionals and the institution, and avoids the occurrence of disallowances ${ }^{(6)}$. Therefore, it is the responsibility of the multidisciplinary team to adequately fill in medical records so as to avoid losses in institutional financial results ${ }^{(7)}$. It should be noted that the documentation of the assistance provided in Surgical Centers comprises a set of information of varied complexities which depicts the quality of the interprofessional practice.

Considering the relevance of investigating the generation of technical disallowances in private hospitals, especially in units of greater weigh in the composition of revenues, this study aimed to analyze the technical disallowances generated in the surgical center of a private general hospital.

\section{Methods}

Retrospective documentary research carried out in the surgical center of a large private general hospital whose physical structure comprises 18 surgical rooms, 19 anesthetic recovery beds, equipment room, arsenal room, locker room, nursing room and nursing ward, pathology room, satellite pharmacy, orthosis/prosthetics/special materials room, room for cleaning materials, comfort and rest, waste disposal room, and purge room.

The surgical team consists of surgeon and anesthesiologist physicians, nurses, nursing technicians/assistants and anesthesia assistants. Nursing professionals are hired by the hospital. The surgeons are part of the clinical staff, are registered to perform surgeries, but are not hired and are therefore assigned as service providers. With regard to anesthesiologist physicians, there are some who are hired and integrate the surgical team, and there are others who are service providers and integrate the teams of the surgeon physicians. In view of this, in order to make possible the future proposition of educational and preventive measures, it was decided to study only the technical disallowances generated by hired professionals who are members of the surgical team.

The nursing team is composed of 10 nurses, distributed as follows: three nurses from $7 \mathrm{~h}-13 \mathrm{~h}$; one from 16h-22h; one from 13h-19h; a nurse who covers the days off of other professionals, one in the evenings of even days and another in uneven days, counting on 
the one in charge from $6 \mathrm{~h}-15 \mathrm{~h}$ and the supervisor from 7h-17h and 81 technicians/assistants, among 31 in the morning, 30 in the afternoon and 10 in each night. The team of hired medical anesthesiologists counts on 30 professionals, aong two physicians on duty who work from $7 \mathrm{~h}-19 \mathrm{~h}$ and the others rotating schedules, from $6 \mathrm{~h}-14 \mathrm{~h}, 7 \mathrm{~h}-16 \mathrm{~h}$ or $8 \mathrm{~h}-19 \mathrm{~h}$. Each surgical room has an anesthesiologist; however, two professionals can be allocated depending on the complexity and duration of the surgery.

The anesthesiologist doctors document the care provided on the anesthesia record and the nurses, technicians/assistants on the trans-operative sheet. In the post-anesthetic recovery room, records are performed by prescription and medical and nursing evolution.

Based on the average of 1,200 surgeries/month that originated 900 accounts with changes made during the negotiation between internal and external auditors, resulting in technical disallowances ("dirty accounts"), that is, $75.0 \%$ of the population of 1,200 medical records, considering the period of three typical months, the following statistical criteria were adopted to obtain the sample size: confidence interval of $95.0 \%(\mathrm{z}=1.96)$; statistical error $5.0 \%(\mathrm{e}=0.05)$ and sample proportion of $50.0 \%(\mathrm{p}=0.5)$. Then, by means of this equation, a sample of 383 medical records was determined.

Medical record with "dirty accounts" and the respective forms used by the surgical team were randomly included. This printed documents were confronted with hospital accounts that listed the items related to the service provided to the patients, according to the following specific accounting groups: "materials", "medicines", "equipment", "gases" and "fees". The fees of the surgical room, the anesthetic recovery room, and the dressing room are considered in this last accounting group. Medical fees and diagnostic and therapeutic support services were not included in the accounting groups because they were documented, analyzed and billed apart from the hospital bill.

Medical records included in the sample were retrieved from the list of patients with medical records containing the invoiced bills. In order to facilitate the registration of the data, a spreadsheet was created with the three following columns: description of the item disallowed per accounting group; specification of the total value relative to the disallowed items; and specification of the surgical team members related to the disallowance.

The evaluation of the percentages of disallowances of items (dependent variable), according to the professional category or the accounting group, was carried out through Generalized Estimating Equation models, a statistical approach that extends generalized linear models to allow the analysis of repeated measures or other correlated observations, accommodating possible dependence between the observations pertaining the same individual. The purpose of this model is to estimate the regression parameter, especially when data are correlated. The Generalized Estimating Equation models were obtained using STATA 12, and the Statistical Package for the Social Sciences 20.0 was used for the other analyses. The significance level of $5.0 \%$ was adopted.

This research complied with the specifications of Resolution 466/2012, which approves guidelines and regulatory norms for research involving human beings and was approved by the Research Ethics Committee of the São Luiz Hospital, through written Opinion $\mathrm{n}^{\circ} 822.825$.

\section{Results}

The resulting bill of service provided for 383 patients, whose records comprised the sample of this study, corresponded to $\mathrm{R} \$ 5,623,968.17$ (100.0\%), with an average total value per hospital account/patient of $\mathrm{R} \$ 14,683.99$ (Standard Deviation $S D=R \$ 13,447.62$ ), ranging from $R \$ 2,638.74$ to $\mathrm{R} \$ 105,567.27$. The disallowed value ranged from $\mathrm{R} \$ 1.06$ to $\mathrm{R} \$ 4,280.69$, with an average of $\mathrm{R} \$ 430.53$ ( $\mathrm{SD}=\mathrm{R} \$ 573.07$ ) and an average percentage of disallowed value of $3.6 \%(\mathrm{SD}=4.55)$. The mean number of 
disallowed items was $3.6(\mathrm{SD}=3.1)$, ranging from 1.0 to 22.0 items per hospital account/patient. Extrapolating the average glossed value per hospital account, it is estimated that the hospital searched would have a total average disallowed value of $\mathrm{R} \$ 387,477.00$, in one month; and $\mathrm{R} \$ 4,649,724.00$, in one year.

According to Table 1, 1,373 items of hospital accounts were disallowed; the majority $(1,128-82.1 \%)$ were disallowances generated by the category "nursing professionals", and the items of the accounting group "materials" were the most disallowed (67.7\%). The percentages of "materials" and "fees", generated by "nursing professionals" (74.0\% and $8.2 \%)$, were higher than those of the "anesthesiologist physician" category (38.4\% and $0.0 \%$ ), indicating, through the Chi-Square test, a highly significant association between accounting group and professional category $(\mathrm{p}<0.001)$. The percentage of disallowances associated to the category "anesthesiologist physicians" was higher in the accounting groups "medicines", "equipment" and "gases", compared to the percentages of the category "nursing professionals". In the accounting group "fees", disallowances were only generated by "nursing professionals" due to the non-performance in the operating room of the registration of room, antisepsis and dressing fees in the form of the collection bulletin.

Table 1 - Distribution of the 1,373 disallowed items per accounting group, according to the professional category that generated the disallowance

\begin{tabular}{lccc}
\hline \multirow{2}{*}{$\begin{array}{l}\text { Accounting } \\
\text { group }\end{array}$} & \multicolumn{2}{c}{ Categories } & Total \\
\cline { 2 - 3 } & $\begin{array}{c}\text { Nursing } \\
\text { professionals } \\
\mathbf{n}(\%)\end{array}$ & $\begin{array}{c}\text { Anesthesiologist } \\
\text { physician } \\
\mathbf{n}(\%)\end{array}$ & n (\%) \\
\hline Materials & $835(74.0)$ & $94(38.4)$ & $929(67.7)$ \\
Medicines & $93(8.2)$ & $88(35.9)$ & $181(13.2)$ \\
Equipment & $68(6.1)$ & $44(17.9)$ & $112(8.1)$ \\
Gases & $39(3.5)$ & $19(7.8)$ & $58(4.2)$ \\
Fees & $93(8.2)$ & $0(0.0)$ & $93(6.8)$ \\
Total & $1.128(100.0)$ & $245(100.0)$ & $1.373(100.0)$ \\
\hline
\end{tabular}

In this study, the analysis of the technical disallowances was supported considering the absolute numbers and percentages of the disallowed items. Thus, considering the categories "nursing professionals" and "anesthesiologist physicians" altogether, the average percentage of disallowed item was $1.0 \%$ $(\mathrm{SD}=1.72)$. In absolute numbers, the number of disallowed items related to the category "nursing professionals" $(1,128)$ was found to be 4.6 times higher than that related to "anesthesiologist physicians" (245). However, the percentage of disallowed items of the category "anesthesiologist physicians" (1.8\%) was 2.25 times higher than the percentage of the "nursing professionals" category $(0.8 \%)$.

As for the mean percentage of items disallowed by the two categories, recalculating the estimate and obtaining the standard error (standard deviation of the estimate), we found a difference of $0.98(\mathrm{p}<0.001)$ between the category "anesthesiologist physicians" and "nursing professionals". Therefore, the estimate of the mean percentage of items disallowed by the category "anesthetist physicians" was higher than that of the category "nursing professionals". The accounting group "equipment" presented the highest percentage of disallowed items $(1.6 \%$ - SD=0.9), especially considering the use of the thermal blankets, a high-cost item $(\mathrm{R} \$ 950.00)$ that had a high impact on the results obtained.

Table 2 shows the estimated difference of the average percentage of disallowed items between accounting groups, using the approach of Generalized Estimation Equations. The estimate of the "equipment" group (1.5\%) was higher than that of "materials" $(1.1 \%)$ and "medicines" $(0.9 \%)$, which in turn were higher than the accounting group "fees" $(0.4 \%)$, and the average percentage estimate of disallowed items in the "gases" group was not statistically significant ( $\mathrm{p}=0.137)$. 
Table 2 - Distribution of mean percentage estimates of disallowed items, according to the accounting group, through the application of the generalized estimation equations approach

\begin{tabular}{lccc}
\hline Accounting group & $\begin{array}{c}\text { Mean percentage } \\
\text { estimate }\end{array}$ & Standard Error & $\mathbf{p}$ \\
\hline Materials & $1.1^{*}$ & 0.06 & $<0.001$ \\
Medicines & $0.9^{*}$ & 0.13 & $<0.001$ \\
Equipment & $1.5^{*}$ & 0.16 & $<0.001$ \\
Gases & 0.3 & 0.22 & 0.137 \\
Fees & $0.4^{*}$ & 0.18 & 0.016 \\
\hline *Present distinct percentage means, according to contrasts, at the global sig- \\
nificance level of 5\%
\end{tabular}

Table 3 - Distribution of the value of the technical disallowances and contribution to the total value of disallowances and to the total value of hospitalizations, according to professional categories and accounting groups

\begin{tabular}{|c|c|c|c|c|}
\hline $\begin{array}{l}\text { Professional category } \\
\text { and accounting group }\end{array}$ & $\begin{array}{l}\text { Disallowan- } \\
\text { ce value } \\
\text { (R\$) }\end{array}$ & $\begin{array}{c}\text { Contribution } \\
\text { to the total } \\
\text { value of disal- } \\
\text { lowances (\%) }\end{array}$ & $\begin{array}{c}\text { Contribution to } \\
\text { the total value } \\
\text { of hospitaliza- } \\
\text { tions* }(\%)\end{array}$ & 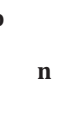 \\
\hline Nursing professionals & $113,332.41$ & 68.7 & 2.0 & 1,128 \\
\hline Materials & $83,396.69$ & 50.6 & 1.5 & 835 \\
\hline Medicines & $11,408.43$ & 6.9 & 0.2 & 93 \\
\hline Equipment & $11,449.65$ & 6.9 & 0.2 & 68 \\
\hline Gases & $1,413.23$ & 0.9 & - & 39 \\
\hline Fees & $5,664.41$ & 3.4 & 0.1 & 93 \\
\hline $\begin{array}{l}\text { Anesthesiologist } \\
\text { physicians }\end{array}$ & $51,560.00$ & 31.3 & 0.9 & 245 \\
\hline Materials & $37,647.00$ & 22.8 & 0.7 & 94 \\
\hline Medicines & $5,529.00$ & 3.4 & 0.1 & 88 \\
\hline Equipment & $7,769.00$ & 4.7 & 0.1 & 44 \\
\hline Gases & 615.00 & 0.4 & - & 19 \\
\hline Fees & - & - & - & - \\
\hline Total & $164,892.41$ & 100.0 & 2.9 & 1,373 \\
\hline
\end{tabular}

Among the 1,373 disallowed items, the majority (67.7\%) were related to the "materials" accounting group, with highlight to the "disposable apron" (118 disallowed units - 12.7\%) and "compress" (66 disallowed units - 7.0\%) items. In the "medicines" group, $38.7 \%$ of the disallowances came from the item "solutions", referring to infused sera, by the category "anesthesiologist physicians" during surgical procedures. In the "equipment" group, $31.3 \%$ of the disallo- wances were related to the items "capnograph", 24.1\% to "mattress/blanket", and $21.4 \%$ to "vacuum". In the "gases" group, $75.9 \%$ of the disallowances referred to the item "oxygen" and, in the "fees" group, the item "antisepsis" was the most expressive $(44.1 \%$ of the disallowances).

According to Table 3, $\mathrm{R} \$ 164,892.41$ (2.9\%) were related to the technical disallowances, being $2.0 \%$ related to the category "nursing professionals" and $0.9 \%$ to the category" anesthesiologist physicians".

\section{Discussion}

Initially, it is indicated as a limitation of the present study the methodological option of not analyzing the participation of the teams of medical surgeons in the production of technical disallowances because they are service providers, not hired by the hospital, what means that the study did not cover all of the documentation produced by the surgical team in the analyzed medical records.

The analysis of the presented results evidenced the impact of the prevalence of disallowance percentages in the "materials" and "medicines" accounting groups generated by nursing professionals and anesthesiologist physicians on the billing of the surgical center surveyed. In a private hospital with an average of 700 hospitalizations/month and 150 surgeries/month, a survey that evaluated resources related to 921 disallowed items, referring to 218 hospital accounts, accounted for a total of $\mathrm{R} \$ 173,603.36$, of which $91.0 \%$ were associated administrative disallowances. The "materials" and "medicines" accounting groups corresponded to the highest percentages of disallowances ${ }^{(8)}$, similar to that found in the present study.

The above highlights the importance of costs associated with the "materials" and "medicines" accounting groups, products consumed in large quantities in health organizations. A study by the Institute for the Study of Supplementary Health analyzing the 
evolution of hospitalization expenditures from 2005 to 2010 for a health plan with coverage in the state of São Paulo, Brazil, also found the aforementioned accounting groups as the main responsible for the increase in costs, corresponding to $57.7 \%$ of hospital expenses $^{(9)}$. It is understood, therefore, that when the items of these groups, especially "materials", are not properly accounted, disallowances occur and compromise the billing process of the service provided.

The management of material resources whose demand has increased due to the technological advances that constantly drive the complexity of care have worried managers of health organizations, regardless of their legal nature. Specifically in private health organizations, managers experience the constant challenge of managing material resources while maintaining competitive prices ${ }^{(10)}$. In these organizations, the management and proper billing of material resources are essential to minimize financial losses and contribute to the receipt, together with the paying sources, of the value relative to the items that were used so as to facilitate care provision. Thus, in terms of auditing accounts, both material resources management and hospital billing have been delineated as promising areas for nurses to act.

As an integrative review reported that the management of material resources is still incipient in the national scenario of the nursing practice, nurses need to gain specific knowledge ${ }^{(11)}$. A research carried out in six teaching hospitals indicates changes in the participation of nurses in planning, purchasing, storaging, distributing and controlling materials. The effective presence of nurses was possible due to their qualification for administrative activities and the knowledge coming from care activities that allow them to act in favor of increasing the available resources, evaluating and considering the choice of materials that best meet the needs of patients and professionals and provide safety to the care provided ${ }^{(12)}$.

Associated with the indispensable nature of material resources management, audits in the health area brings benefits to institutions (raising proves of adequate and fair expenses) and patients (improvement of the quality and satisfaction with the assistance received), and such actions require properly trained professionals. Audits represent another expanding area for nurses to optimize costs, avoid wastage, ensure that procedures are properly performed ${ }^{(13)}$ and produces proves of the adequacy of health care provision and associated costs, in order to provide support for the financial transfer in the supplementary health segment $^{(14)}$.

Based on the clinical experience, the authors of this study verified that, in the surgical center researched, nursing professionals often manipulate, in greater quantity, the material resources, while anesthesiologist physicians manipulate medicines. However, these particularities of the work processes do not justify the percentage of disallowances caused by failures in nursing notes, medical and nursing prescriptions and checkings, which incurred financial losses to the institution studied.

Although the category "nursing professionals" was responsible for most of the disallowed items, the category "anesthesiologist physicians" presented the highest percentage of items disallowed per patient. Considering that in the hospital that was field of the present study, anesthesiologists administer high-cost materials, medicines, equipment, and gases, this percentage is highly relevant when transformed into currency because although the quantity of items is not high, in absolute numbers, such quantity corresponds to a significant financial loss in hospital bills, incurring in hospital billing losses.

It is known that the registration of nursing care is considered of great value for the success of the audit, by subsidizing the evaluation, control and verification of nonconformities in the actions and, thus, implementing an educational action plan ${ }^{(13)}$. However, although the nursing notes contribute to the recovery 
of the values related to the disallowed items, it is reiterated that adequate documentation of health professionals serves as legal support for the institution, the professionals themselves and the patient, confirming the care provided, and also facilitating the work of auditors to explain the resources of disallowances for healthcare plans ${ }^{(2)}$.

Although recurrent searches in the literature were conducted, no studies were found on the failures in the documentation of other health professional categories besides nursing, indicating a knowledge gap on this theme.

Studies have demonstrated the financial repercussion of inadequate documentation of care measures provided by nursing professionals, emphasizing the importance of investments in educational actions $^{(6-8,15)}$, and there is therefore a need for these actions to be performed also by other health professionals. When these professionals, in fact, share responsibility for healthcare billing, divergences/inadequacies in the records will be avoided/minimized, reducing the disallowances of items in hospital bills.

It is essential that health professionals keep a proper record of the procedures performed necause this is not only an ethical and legal responsibility ${ }^{(4-5)}$, but also has the potential to bring favorable effects on the interprofessional practice and improve the economic results of the institutions in which they work, minimizing financial losses whose consequences can directly or indirectly affect them.

It is agreed that, in different health service provision contexts, the interprofessional practice that recognizes the possible replacement of fragmentation by articulation and integration of health actions needs to be made explicit. This has the potential to increase the resolubility of the services and the quality of health care, to broaden and improve communication among professionals and to acknowledge the specific contributions of each area and their overlapping bor$\operatorname{ders}^{(16-17)}$.

\section{Conclusion}

The analysis of hospital accounts allowed the calculation of the number of technical disallowances, with a total of 1,373 items. Nursing professionals were responsible for most of the disallowed items, and the "materials" accounting group predominated, contributing to the search for alternatives that increase billing in the surgical center studied.

\section{Collaborations}

Zunta RSB and Lima AFC contributed to the conception and design; analysis and interpretation of data; writing of the article; relevant critical revision of the intellectual content and final approval of the version to be published.

\section{References}

1. Silva JASV, Hinrichsen SL, Brayner KAC, TAS Vilella, Lemos MC. Glosas hospitalares e o uso de protocolos assistenciais: revisão integrativa da literatura. Rev Adm Saúde [Internet]. 2017 [citado 2018 jun. 15]; 17(66). Disponível em: http://www.cqh.org.br/ojs-2.4.8/index.php/ras/ article/view/13

2. Guerrer GF, Lima AFC, Castilho V. Study of billing audits in a teaching hospital. Rev Bras Enferm. 2015; 68(3):414-20. doi: http://dx.doi. org/10.1590/0034-7167.2015680306i

3. Associação Brasileira de Enfermeiros de Centro Cirúrgico, Recuperação Anestésica e Centro de Material e Esterilização - SOBECC. Práticas recomendadas SOBECC: centro de material e esterilização, centro cirúrgico, recuperação pósanestésica. São Paulo: Manole; 2013.

4. Conselho Federal de Medicina (BR). Resolução CFM no 2.145/2016. Código de Ética Médica. Capítulo X - Documentos médicos [Internet]. 2016 [citado 2018 jan. 13]. Disponível em: http://www. cremesp.org.br/library/modulos/publicacoes/ pdf/CodigoEticaMedica2013.pdf 
5. Conselho Federal de Enfermagem (BR). Resolução COFEN no 564/2017. Código de Ética dos Profissionais de Enfermagem [Internet]. 2017 [citado 2018 jan. 13]. Disponível em: http://www.cofen.gov.br/resolucao-cofenno-5642017_59145.html

6. Dorne J, Hungare JV. Conhecimentos teóricos de auditoria em enfermagem. Rev UNINGÁ [Internet]. 2013 [citado 2018 jan. 13]; 15(1):11-7. Disponível em: https://www.mastereditora.com. br/periodico/20130723_000516.pdf

7. Silva JS. Auditoria em saúde: um novo paradigma na qualidade da assistência de enfermagem. Rev Enferm UFPI [Internet]. 2015 [citado 2018 jan. 13]; 4(2):130-4. Disponível em: http://www.ojs. ufpi.br/index.php/reufpi/article/view/2318

8. Santos MP, Rosa CDP. Auditoria de contas hospitalares: análise dos principais motivos de glosas em uma instituição privada. Rev Fac Ciênc Méd Sorocaba [Internet]. 2013 [citado 2018 jan. 13]; 15(4):125-32. Disponível em: https:// revistas.pucsp.br/index.php/RFCMS/article/ view/17653/pdf

9. Santos GMMS. Materiais e medicamentos: vetores de custo no setor de saúde suplementar. Série IESS- Instituto de Estudos de Saúde Suplementar [Internet]. 2013 [citado 2018 jan. 10]; 1-13. Disponível em: http://documents.scribd.com. s3.amazonaws.com/docs/51azgxi1ds3oglmy.pdf

10. Castilho V, Mira VL, Lima AFC. Gerenciamento de recursos materiais. In: Kurcgant P, coordenadora. Gerenciamento em Enfermagem. Rio de Janeiro: Guanabara Koogan; 2016. p.145-57.

11. Garcia SD, Gil RB, Haddad MCL, Vannuchi MTO, Costa DB. The role of a nurse in the management of medical-hospital material: an integrative review. Online Braz J Nurs. 2013; 12(2):411-26.doi:http:// dx.doi.org/10.5935/1676-4285.20133791
12. Bogo PC, Bernardino E, Castilho V, Cruz EDA. The nurse in the management of materials in teaching hospitals. Rev Esc Enferm USP. 2015; 49(4):632-9.doi:http://dx.doi.org/10.1590/ S0080-623420150000400014

13. Siqueira PLF. Auditoria em saúde e atribuições do enfermeiro auditor. Cad Saúde Desenvolvimento [Internet]. 2014 [citado 2018 mai. 7]; 3(2):5-19. Disponível em: https://www.uninter.com/revistasaude/index.php/cadernosaudedesenvolvimento/article/view/303/234

14. Grossi LM, Pisa IT, Marin HF. Oncoaudit: development and evaluation of an application for nurse auditors. Acta Paul Enferm. 2014; 27(2):17985.doi:http://dx.doi.org/10.1590/19820194201400031

15. Vidoto S, Marisco NS. As glosas hospitalares no contexto da enfermagem em uma instituição hospitalar. Rev Espaç Ciênc Saúde [Internet]. 2015 [citado 2018 jan. 13]; 3(1):15-27. Disponível em: http://revistaeletronica.unicruz.edu.br/index. php/enfermagem/article/view/5273

16. Peduzzi M, Norman IJ, Germani ACCG, Silva JAM, Souza GC. Interprofessional education: training for healthcare professionals for teamwork focusing on users. Rev Esc Enferm USP. 2013; 47(4):977-83. doi: http://dx.doi.org/10.1590/ S0080-623420130000400029

17. Sevin AM, Hale KM, Brown NV, McAuley JW. Assessing Interprofessional Education Collaborative Competencies in Service-Learning Course. Am J Pharm Educ [Internet]. 2016 [cited 2018 Feb. 26]; 80(2):32. Available from: https://www.ncbi.nlm.nih.gov/pmc/articles/ PMC4827583/ 